Marquette University

e-Publications@Marquette

Theology Faculty Research and Publications

Theology, Department of

$1-1-2008$

\title{
Praxis of the Voice: The Divine Name Traditions in the Apocalypse of Abraham
}

Andrei Orlov

Marquette University, andrei.orlov@marquette.edu

Published version. Journal of Biblical Literature, Vol. 127, No. 1 (2008). Publisher link. (C) 2008

Society of Biblical Literature. Used with permission. 


\title{
Praxis of the Voice: The Divine Name Traditions in the Apocalypse of Abraham
}

\author{
ANDREI A. ORLOV \\ andrei.orlov@mu.edu \\ Marquette University, Milwaukee, WI 53201
}

A large portion of the Apocalypse of Abraham, a Jewish work known only in its Slavonic translation, deals with the celestial tour of the eponymous hero of the text. In the work's elaborate account of the tour, which depicts Abraham's initiation into the heavenly mysteries, an important detail often found in other apocalyptic texts is missing. The authors of the Slavonic work seem deliberately to eschew anthropomorphic depictions of the deity that often mark climactic points in other early Jewish apocalyptic accounts. This reluctance to endorse traditions of the divine form appears to be quite unusual, given that other features of the pseudepigraphon exhibit explicit allusions to motifs and themes of the Merkabah tradition. Several distinguished scholars of early Jewish mysticism have previously noted that the Apocalypse of Abraham might represent one of the earliest specimens of Merkabah mysticism, the Jewish tradition in which the divine form ideology arguably receives its most advanced articulation. ${ }^{1}$ Yet despite many suggestive allusions in

${ }^{1}$ On the Jewish mystical traditions in the Apocalypse of Abraham, see George H. Box and Joseph I. Landsman, The Apocalypse of Abraham (Translations of Early Documents; London: SPCK, 1918), xxix-xxx; Mary Dean-Otting, Heavenly Journeys: A Study of the Motif in Hellenistic Jewish Literature (Judentum und Umwelt 8; Frankfurt am Main: Lang, 1984), 251-53; Ithamar Gruenwald, Apocalyptic and Merkavah Mysticism (AGJU 14; Leiden: Brill, 1980), 55-56; David J. Halperin, The Faces of the Chariot: Early Jewish Responses to Ezekiel's Vision (TSAJ 16; Tübingen: Mohr Siebeck, 1988), 103-13; Alexander Kulik, Retroverting the Slavonic Pseudepigrapha: Toward the Original of the Apocalypse of Abraham (Text-critical Studies 3; Leiden/Boston: Brill, 2004), 83-88; Belkis Philonenko-Sayar and Marc Philonenko, L'Apocalypse d'Abraham: Introduction, texte slave, traduction et notes (Semitica 31; Paris: Adrien Maisonneuve, 1981), 28-33; Christopher Rowland, The Open Heaven: A Study of Apocalyptic in Judaism and Early Christianity (New York: 
their depiction of the heavenly realities, the authors of the Apocalypse of Abraham appear very reluctant to endorse one of the most crucial tenets in the divine chariot lore: the anthropomorphic depiction of the Glory of God. The reluctance seems rather puzzling in view of some close similarities in angelological imagery that the Apocalypse of Abraham shares with the first chapter of the book of Ezekiel, the formative account of the Merkabah tradition, where the ideology of the divine form looms large. ${ }^{2}$

It has been previously noted that the seer's vision of the divine throne found in the Apocalypse of Abraham relies significantly on Ezekiel's account and stands in direct continuity with Merkabah tradition. ${ }^{3}$ At the same time, however, scholars observe that the Slavonic pseudepigraphon shows attempts to depart from the overt anthropomorphism of this prophetic book. Christopher Rowland, for example, notes that the shift from anthropomorphism is apparent in the portrayal of the divine throne in ch. 18 of the Apocalypse of Abraham. Notwithstanding the many allusions to Ezekiel 1 in the depiction of the throne room in chs. 18 and 19 of the Apocalypse, Rowland highlights a radical paradigm shift in the text's description of the deity, noting "a deliberate attempt ... to exclude all reference to the human figure mentioned in Ezek 1." For Rowland, this shift entails that "there was a definite trend within apocalyptic thought away from the direct description of God."

Crossroad, 1982), 86-87; Ryszard Rubinkiewicz, L'Apocalypse d'Abraham en vieux slave: Édition critique du texte, introduction, traduction et commentaire (Towarzystwo Naukowe Katolickiego Uniwersytetu Lubelskiego: Źródła i monografie 129; Lublin: Société des lettres et des sciences de l'Université catholique de Lublin, 1987), 76-83; Michael E. Stone "Apocalyptic Literature," in Jewish Writings of the Second Temple Period: Apocrypha, Pseudepigrapha, Qumran Sectarian Writings, Philo, Josephus (ed. M. E. Stone; CRINT 2/2; Assen: Van Gorcum, 1984), 383-441; Gershom Scholem, Major Trends in Jewish Mysticism (New York: Schocken Books, 1961), 52, 57-61, 72; idem, Jewish Gnosticism, Merkabah Mysticism, and Talmudic Tradition (New York: Jewish Theological Seminary, 1965), 23-24; idem, Kabbalah (Library of Jewish Knowledge; New York: Quadrangle, 1974), 18.

${ }^{2}$ Ryszard Rubinkiewicz provides a helpful outline of usage of Ezekielian traditions in the Apocalypse of Abraham (L'Apocalypse d'Abraham, 87). He notes that "among the prophetic books, the book of Ezekiel plays for our author the same role as Genesis in the Pentateuch. The vision of the divine Throne (Apoc. Ab. 18) is inspired by Ezek 1 and 10. Abraham sees the four living creatures (Apoc. Ab. 18:5-11) depicted in Ezek 1 and 10. He also sees the wheels of fire decorated with eyes all around (Apoc. Ab. 18:3), the throne (Apoc. Ab. 18:3; Ezek 1:26), the chariot (Apoc. Ab. 18:12 and Ezek 10:6); he hears the voice of God (Apoc. Ab. 19:1 and Ezek 1:28). When the cloud of fire rises up, he can hear 'the voice like the roaring sea' (Apoc. Ab. 18:1; Ezek 1:24). There is no doubt that the author of the Apocalypse of Abraham takes the texts of Ezek 1 and 10 as sources of inspiration."

${ }^{3}$ John J. Collins, The Apocalyptic Imagination: An Introduction to Jewish Apocalyptic Literature (2nd ed.; Grand Rapids: Eerdmans, 1998), 228-29. Collins also notes that Abraham's vision "stands in the tradition of $1 \mathrm{En}$. 14, conveying a sense of the visionary's experience of awe and terror" (p. 229).

${ }^{4}$ Rowland, Open Heaven, 86-87. 
These observations about anti-anthropomorphic tendencies of the Slavonic apocalypse are intriguing and deserve further investigation. Even a cursory look at the text reveals that, despite an extensive appropriation of the visionary motifs and themes, the authors appear to be avoiding anthropomorphic depictions of the deity and some other celestial beings. ${ }^{5}$ This tendency leads to the creation of a new apocalyptic imagery that combines traditional and novel elements. This article will investigate these new conceptual developments in the Apocalypse of Abraham and seek to understand their place in the larger anticorporeal ideology of the Slavonic pseudepigraphon.

\section{The Biblical Background of the Shem Tradition}

The Apocalypse of Abraham is a Jewish work probably composed in Palestine in the early centuries of the Common Era. ${ }^{6}$ The text can be divided into two parts. ${ }^{7}$

${ }^{5}$ Anti-anthropomorphic reinterpretation of Ezekiel's vision can be detected also in the Targums. For extensive discussion of the avoidance of anthropomorphism in the Targum to Ezekiel 1, see Halperin, Faces of the Chariot, 120-23.

${ }^{6}$ On the date and provenance of the Apocalypse of Abraham, see Box and Landsman, Apocalypse of Abraham, xv-xix; Philonenko-Sayar and Philonenko, L'Apocalypse d'Abraham. 34-35; Ryszard Rubinkiewicz, "Apocalypse of Abraham," OTP 1:681-705, at 683; idem, L'Apocalypse d'Abraham en vieux slave, 70-73; Alexander Kulik, "К датировке 'Откровения Авраама"' [About the Date of the Apocalypse of Abraham], in In Memoriam: Ja. S. Lur'e (ed. N. M. Botvinnik and Je. I. Vaneeva; St. Petersburg, 1997), 189-95; idem, Retroverting the Slavonic Pseudepigrapha, 2-3.

${ }^{7}$ For the published Slavonic manuscripts and fragments of the Apoc. Ab., see Ioan Franko, "Книга о Аврааме праотци и патриарси" [The Book about the Forefather and the Patriarch Abraham], in Апокріби і легенди з українських рукописів [The Apocrypha and the Legends from the Ukrainian Manuscripts](5 vols.; Monumenta Linguae Necnon Litterarum UkrainoRussicarum [Ruthenicarum] 1-5; L’vov: Schevchenka, 1896-1910), 1:80-86; Alexander I. Jacimirskij, "Откровение Авраама" [The Apocalypse of Abraham], in Библиографический обзор апокрифов в южнославянской и русской письменности (Списки памятников) Выпуск 1. Апокрифы ветхозаветные [The Bibliographical Survey of Apocryphal Writings in South Slavonic and Old Russian Literature, vol. 1, The Old Testament Pseudepigrapha] (Petrograd: Russian Imperial Academy of Sciences, 1921), 99-100; P. P. Novickij, ed., "Откровение Авраама" [The Apocalypse of Abraham], in Общество любителей древней письменности [The Society of Lovers of Ancient Literature] 99.2 (St. Petersburg: Markov, 1891); Ivan Ja. Porfir'ev, “Откровение Авраама" [The Аросаlypse of Abraham], in Апокрифические сказания о ветхозаветных лицах и событиях по рукописям соловеикой библиотеки [Тhe Apocryphal Stories about Old Testament Characters and Events according to the Manuscripts of the Solovetzkoj Library] (Sbornik Otdelenija russkogo jazyka i slovesnosti Imperatorskoj akademii nauk 17.1; St. Petersburg: Russian Academy of Sciences, 1877), 111-30; Philonenko-Sayar and Philonenko, L'Apocalypse d'Abraham, 36-105; Alexander N. Pуріn, Ложные и отреченные книги славянской и русской старины, Памятники старинной русской литературы, издаваемые грабом Григорием Кушелевым-Безбородко Том 3 [The False and Rejected Books of Slavonic and 
The first part (chs. 1-8) of the work represents a haggadic account of Abraham's rejection of the religious practices of his father, Terah. The second, apocalyptic part covers the rest of the work (chs. 9-32) and depicts the patriarch's ascension to heaven, where he is accompanied by his angelus interpres, Yahoel, during his initiation into the heavenly and eschatological mysteries.

The first eight chapters of the pseudepigraphon take the form of midrashic elaboration and recount the early years of Abraham, who is depicted as a reluctant helper to his idolatrous father, Terah. The conceptual developments found in this section of the work, especially in the depictions of the idolatrous figures, seem to play an important role in the work's overall retraction of the anthropomorphic understanding of the deity. Possibly mindful of the broader extrabiblical context of Abraham's biography and his role as the fighter against the idolatrous practices of his father, the work's authors seem to be appropriating the patriarch's story for their anticorporeal agenda. ${ }^{8}$ In the depictions of the idol Bar-Eshath ("the Son of Fire") ${ }^{9}$ and some other humanlike figures, whose features are vividly reminiscent of the familiar attributes of the anthropomorphic portrayals of the deity in Ezekiel and

Russian Antiquity: Memorials of Ancient Russian Literature Edited by Count Gregory KushelevBezborodko, vol. 3 (St. Petersburg: Kulesh, 1860-62), 24-36; Rubinkiewicz, L'A pocalypse d'Abraham en vieux slave, 98-256; Izmail I. Sreznevskij, "Книги Откровения Авраама" [The Apocalypse of Abraham], in Известия Императорской академии наук по отделению русского языка и словесности. Том 10 [Proceedings of the Imperial Academy of Sciences, Division of Russian Language and Literature, vol. 10] (St. Petersburg: Russian Academy of Sciences, 1861-63), 648-65; Nikolaj S. Tihonravov, Памятники отреченной русской литературы [Memorials of Russian Apocryphal Literature] (2 vols.; St. Petersburg/Moscow: Obschestvennaja Pol'za, 1863), 1:32-77.

For the translations of the Apoc. Ab., see Nathanael Bonwetsch, Die Apokalypse Abrahams: Das Testament der vierzig Märtyrer (Studien zur Geschichte der Theologie und der Kirche, Bd.1, Heft 1; Leipzig: Deichert, 1897); Box and Landsman, Apocalypse of Abraham, 35-87; Mario Enrietti and Paolo Sacchi, "Apocalisse di Abramo," in Apocrifi dell'Antico Testamento (ed. Paolo Sacchi et al.; 5 vols.; Turin/Brescia: Unione tipografico-editrice torinese, 1981-97), 3:61-110; Kulik, Retroverting the Slavonic Pseudepigrapha, 9-35; A. Pennington, "Apocalypse of Abraham," AOT, 363-491; Donka Petkanova, "Откровение на Авраам" [The Apocalypse of Abraham], in Старобългарска Есхатология. Антология [Old Bulgarian Eschatology: Anthology] (ed. D. Petkanova and A. Miltenova; Slavia Orthodoxa; Sofiya: Slavica, 1993), 17-30; Belkis PhilonenkoSayar and Marc Philonenko, "Die Apokalypse Abrahams," JSHRZ 5.5 (Gütersloh: Mohn, 1982), 413-60; Paul Rießler, "Apokalypse des Abraham," in Altjüdisches Schrifttum außerhalb der Bibel (Freiburg: F. H. Kerle, 1928), 13-39; 1267-69; Rubinkiewicz, "Apocalypse of Abraham," OTP 1:681-705; idem, "Apocalypsa Abrahama," in Apokryfy Starego Testamentu (ed. R. Rubinkiewicz; Warsaw: Oficyna Wydawnicza "Vocatio," 1999), 460-81.

${ }^{8}$ For the background of this story in the book of Jubilees, Josephus, Philo, and the later rabbinic materials (Gen. Rab. 38:13; Tanna debe Eliahu 2:25; S. Eliahu R. 33), see Box and Landsman, Apocalypse of Abraham, 88-94; Rubinkiewicz, L'Apocalypse d'Abraham en vieux slave, 43-49.

${ }^{9}$ On Bar-Eshath and the background of this name, see Kulik, Retroverting the Slavonic Pseudepigrapha, 63. 
some other biblical and pseudepigraphical accounts, one can detect a subtle polemic against the divine body traditions. I have previously discussed the scope and nature of the anti-anthropomorphic developments in the first part of the Apocalypse of Abraham. ${ }^{10}$ The current article can be seen as a continuation of the ongoing inquiry into the anti-anthropomorphic tendencies of the Apocalypse, as it will deal with the polemical developments in the second, apocalyptic section of the pseudepigraphon. The second portion of the Slavonic pseudepigraphon takes the form of a visionary account and deals with celestial and eschatological revelations to Abraham after his open renunciation of idolatrous practices.

One of the important features of this section of the text is the authors' apparent anti-anthropomorphic attitude, reflected in their peculiar portrayals of the deity and the heavenly hosts in chs. 8-19. Although the apocalyptic imagery found in this portion of the pseudepigraphon appears to stem from the theophanic paradigm of the early Merkabah speculations, similar to those found in Ezekiel 1, 1 Enoch $14,{ }^{11}$ and the Exagoge of Ezekiel the Tragedian, the authors of the Slavonic text appear to exhibit consistent efforts to refashion this traditional theophanic imagery in accordance with a new anti-anthropomorphic template that insists on expressing the divine presence in the form of the deity's voice. ${ }^{12}$ In his comparative analysis of the accounts from Ezekiel and the Apocalypse of Abraham, Rowland notes that, while preserving the angelology of Ezekiel's account, the author of the Slavonic apocalypse carefully avoids anthropomorphic descriptions of the Kavod, replacing them with references to the divine voice.

These anti-anthropomorphic tendencies can be observed already in the very beginning of the apocalyptic section of the work. The very first manifestation of the deity to the seer found in ch. 8 takes the form of a theophany of the divine voice, depicted as coming from heaven in a stream of fire. ${ }^{13}$ This peculiar expression of

${ }^{10}$ Andrei A. Orlov, "The Gods of My Father Terah": Abraham the Iconoclast and the AntiAnthropomorphic Tendencies of the Apocalypse of Abraham (forthcoming).

${ }^{11}$ George W. E. Nickelsburg notices that "Abraham's ascent and throne vision stand in a tradition that stretches from 1 En. 12-16 to the medieval mystical texts" ( Jewish Literature between the Bible and the Mishnah: A Historical and Literary Introduction [2nd ed.; Minneapolis: Fortress, 2005], 288).

${ }^{12}$ On the hypostatic voice of God, see James H. Charlesworth, "The Jewish Roots of Christology: The Discovery of the Hypostatic Voice," SJT 39 (1986): 19-41.

${ }^{13}$ Scholars have previously noted that the patriarch's vision reflected in the second part of the Slavonic apocalypse seems to be reminiscent not only of Ezekiel 1 but also of the visionary account in Genesis 15 ("with an allusion to Gen 22 insofar as the sacrifices are located on a high mountain" [Collins, Apocalyptic Imagination, 226]). Thus, Box notes that "the apocalyptic part of the book is based upon the story of Abraham's sacrifices and trance, as described in Gen. Xv" (Box and Landsman, Apocalypse of Abraham, xxiv). In both Genesis and the Apocalypse of Abraham, the patriarch is asked to prepare sacrifices, and the content of the sacrifices is also very similar. Yet the theophanic tradition of the divine voice does not play a prominent role in Genesis 15. Although the latter text mentions the word of God given to Abraham, it does not say anything 
the deity as the voice erupting in a fiery stream will subsequently become a customary theophanic expression, appearing multiple times in the apocalypse, including in the climactic account of the revelation given to Abraham in the seventh firmament. There, in his vision of the throne room, which evokes memories of Ezekelian angelology, the hero of the faith sees not the humanlike form of God but the deity's formless voice.

This tendency to replace the anthropomorphic depiction of the deity with expressions of the divine voice or name is, of course, not a novel development of the authors of the Apocalypse of Abraham but a specimen of the long-lasting tradition whose roots can be found already in the biblical materials.

The Hebrew Bible reveals complicated polemics for and against anthropomorphic understandings of God. Scholars argue that the anthropomorphic imagery found in biblical materials was "crystallized" in the Israelite priestly ideology known to us as the Priestly source. Moshe Weinfeld points out that the theology of worship delineated in the Priestly source depicts God in "the most tangible corporeal similitudes." ${ }^{14}$ In the Priestly tradition God is understood to have created humanity in his own image (Gen 1:27) and is thus frequently described as possessing a humanlike form. ${ }^{15}$ Scholars have shown that the anthropomorphism of the Priestly authors appears to be intimately connected with the place of divine habitation - the deity possesses a human form and needs to reside in a house or tabernacle. ${ }^{16}$ Weinfeld argues that the anthropomorphic position was not entirely an invention of the Priestly tradition but derived from early preexilic sacral conceptions about divine corporeal manifestations found in Mesopotamian literature. ${ }^{17}$ Scholars observe that the Priestly understanding of the corporeal representation of the deity finds its clearest expression in the conception of the "Glory of God" (כבוד יהוה). ception is always expressed in the Priestly tradition in the symbolism grounded in mythological corporeal imagery. One of the paradigmatic accounts of the portrayal of the divine Kavod can be found in the first chapter of the book of Ezekiel, which can be seen as the manifesto of the Priestly corporeal ideology. There the Kavod is portrayed as an enthroned human form enveloped by fire.

\footnotetext{
about the voice in the fire, a standard theophanic formula found in the Apocalypse of Abraham. It is also noteworthy that at the end of the Genesis account, the patriarch sees the vision of a fiery phenomenon-a smoking fire pot with a blazing torch.

${ }^{14}$ Moshe Weinfeld, Deuteronomy and the Deuteronomic School (Oxford: Clarendon, 1972), 191.

${ }^{15}$ Ludwig Köhler (“Die Grundstelle der Imago-Dei Lehre, Genesis i, 26," TZ 4 [1948]: 1617) and Weinfeld (Deuteronomy and the Deuteronomic School, 199) argue that the phrase, "in our image, after our likeness" precludes the anthropomorphic interpretation that the human being was created in the divine image.

${ }^{16}$ Weinfeld, Deuteronomy and the Deuteronomic School, 191.

${ }^{17}$ Ibid., 199.

${ }^{18}$ Ibid., 200-201.
} 
While containing forceful anthropomorphic ideologies, the Hebrew Bible also attests to polemical narratives contesting the corporeal depictions of the deity. Scholars have long noted a sharp opposition in the book of Deuteronomy and the Deuteronomic school to early anthropomorphic developments. In fact, the Deuteronomic school is widely thought to have initiated the polemic against the anthropomorphic and corporeal conceptions of the deity, which was subsequently adopted by the prophets Jeremiah and Deutero-Isaiah. ${ }^{19}$ Seeking to dislodge ancient anthropomorphism, the book of Deuteronomy and the Deuteronomic school promulgated an anticorporeal theology of the divine name with its conception of sanctuary (tabernacle) as the exclusive dwelling of God's Name..$^{20}$ Gerhard von Rad argues that the Deuteronomic formula "to cause his name to dwell" (לשכן שמו) advocates a new understanding of the deity that challenges the popular ancient belief that God actually dwells within the sanctuary. ${ }^{21}$ It is noteworthy that, although the Deuteronomic Shem ideology does not completely abandon the terminology pertaining to the concept of the divine glory (Kavod), ${ }^{22}$ it markedly voids it of any corporeal motifs. Weinfeld observes that "the expression כבוד, when occurring in Deuteronomy, does not denote the being and substantiality of God as it does in the earlier sources but his splendor and greatness," signifying "abstract and not corporeal qualities." ${ }^{23}$

One of the early examples of the polemical interaction between the corporeal ideology of the divine form (Kavod), which is often labeled in the theophanic accounts as the divine face (Panim), and the incorporeal theology of the divine name possibly occurs in Exodus 33, where, upon Moses' plea to behold the divine Kavod, the deity offers an aural alternative by promising to reveal to the seer his name:

Then Moses said, "Now show me your glory (כבדך)." And the Lord said, "I will cause all my goodness to pass in front of you, and I will proclaim my name (וקראתי בשם), the LorD, in your presence ... but," he said, "you cannot see my face (פני בשי), for no one may see me and live." (Exod 33:18-20)

This account appears to highlight the opposition between visual and aural revelations, focusing on the possibility of encountering the deity not only through

${ }^{19}$ Ibid., 198.

${ }^{20}$ Tryggve N. D. Mettinger observes that the concept of God in the Shem theology is "strikingly abstract... God himself is no longer present in the Temple, but only in heaven. However, he is represented in the Temple by his Name" (The Dethronement of Sabaoth: Studies in the Shem and Kabod Theologies [ConBOT 18; Lund: Wallin \& Dalholm, 1982], 124). See also Weinfeld, Deuteronomy and the Deuteronomic School, 193.

${ }^{21}$ Weinfeld, Deuteronomy and the Deuteronomic School, 193.

${ }^{22}$ This tendency for polemical reinterpretation of the imagery of the rival paradigm is also observable in the Kavod tradition, which in its turn uses the symbolism of the divine voice and other aspects of the Shem symbolism.

${ }^{23}$ Weinfeld, Deuteronomy and the Deuteronomic School, 206. 
the form but also through the sound. One mode of revelation often comes at the expense of the other-the idea hinted at in Exodus 33 and articulated more explicitly in Deut 4:12, "You heard the sound of words, but saw no form (תמונה)." Scholars point to a paradigm shift in Deuteronomy's switch of the revelatory axis from the visual to the aural plane. ${ }^{24}$ In this new, theo-aural, as opposed to theo-phanic, understanding, even God's revelation to Moses on Mount Sinai in Exodus 19, an event marking a vital nexus of the visual anthropomorphic paradigm, becomes now reinterpreted in the terms of its aural counterpart. Deuteronomy 4:36 describes the Sinai theophany as the hearing of the divine voice: "Out of heaven he let you hear his voice, that he might discipline you; and on earth he let you see his great fire and you heard his words out of the midst of the fire." Here the revelation is received not in the form of tablets, the media that might implicitly underline the corporeality of the deity; rather "the commandments were heard from out of the midst of the fire ... uttered by the Deity from heaven." ${ }^{25}$ This transcendent nature of the deity's revelation that now chooses to manifest itself as the formless voice in the fire eliminates any need of its corporeal representation in the form of the anthropomorphic glory of God.

The depiction of the deity's activity and presence as the voice in the fire thus becomes one of the distinctive features of the Shem theology. ${ }^{26}$ The classic example of this imagery can be found in the account of God's appearance to Elijah on Mount Horeb in 1 Kgs 19:11-13:

He said, "Go out and stand on the mountain before the LorD, for the LorD is about to pass by." Now there was a great wind, so strong that it was splitting mountains and breaking rocks in pieces before the LORD, but the LORD was not in the wind; and after the wind an earthquake, but the LoRD was not in the earthquake; and after the earthquake a fire, but the LORD was not in the fire; and after the fire a sound of sheer silence. When Elijah heard it, he wrapped his face in his mantle and went out and stood at the entrance of the cave. Then there came a voice to him that said, "What are you doing here, Elijah?"

This passage vividly recalls the description found in ch. 8 of the Apocalypse of Abraham, where the deity is described as "the voice of the Mighty One coming down from the heavens in a stream of fire." And although the fire is not mentioned directly in the account in 1 Kings 19, the fiery nature of the divine voice is implicitly reaffirmed through the portrayal of the seer wrapping his face in the mantle to shield himself from the dangerous nature of the encounter with the divine voice.

${ }^{24}$ Ibid., 207.

${ }^{25}$ Ibid.

${ }^{26}$ Mettinger notes that "it is not surprising that the Name of God occupies such central position in a theology in which God's words and voice receive so much emphasis" (Dethronement of Sabaoth, 124). 


\section{The Voice of the Mighty One: The Aural Mysticism of the Apocalypse of Abraham}

Keeping in mind the aforementioned biblical specimens relating to the Kavod and the Shem conceptual developments, we will next examine the imagery of the divine presence in the Apocalypse of Abraham.

\section{The Revelation of the Divine Sound}

Depictions of theophanies of the divine voice in the Apocalypse of Abraham reveal marked similarities to the traditions in Deuteronomic and Deuteronomistic materials. ${ }^{27}$ Already in ch. 8 , which marks a transition to the apocalyptic section of the work and narrates the patriarch's response to the divine call in the courtyard of Terah's house, the divine presence is depicted as "the voice of the Mighty One" coming down in a stream of fire. ${ }^{28}$ This self-disclosure of God in the formless "voice" (Slav. глас) rather than some angelic or divine form becomes a standard description adopted by the author(s) of the apocalypse to convey manifestations of the deity. ${ }^{29}$

The divine voice appears continually in the narrative. More notably, in Apoc. Ab. 9:1 the voice of "the primordial and mighty God" commands Abraham to bring sacrifices, and in ch. 10 it appoints the angel Yahoel as a celestial guide of the exalted patriarch.

Similar to the developments in the Kavod tradition, the aural expression of the deity evokes veneration. The epiphany of the divine voice is repeatedly depicted as accompanied by the veneration of the seer, in a fashion that recalls the veneration of the Kavod in the apocalyptic visionary accounts. Thus, in the dramatic portrayal of the seer's encounter of the aural revelation of the deity in Apoc. Ab. 10:1-3,

${ }^{27}$ The affinities with the Deuteronomic materials can be seen also in the implicit and explicit connections between the vision of Abraham and the Deuteronomic version of Moses' Sinai encounter. In this respect David Halperin notes that the author of the Apocalypse of Abraham 'gives us several clues that he is modeling Abraham's experience after Moses' at Sinai. The most obvious of these is his locating the experience at Mount Horeb, the name that Deuteronomy regularly uses for Sinai" (Faces of the Chariot, 109-10). Halperin also notices the allusion to the Deuteronomistic traditions, including the story of Elijah.

${ }^{28}$ Apoc. Ab. 8:1: "The voice (глас) of the Mighty One came down from heaven in a stream of fire, saying and calling, 'Abraham, Abraham!'” Kulik, Retroverting the Slavonic Pseudepigrapha, 16; Philonenko-Sayar and Philonenko, L'Apocalypse d'Abraham, 54.

${ }^{29}$ See, e.g., Aрос. Ab. 18:2 "And I heard a voice (глас) like the roaring of the sea, and it did not cease because of the fire." Kulik, Retroverting the Slavonic Pseudepigrapha, 24; PhilonenkoSayar and Philonenko, L'Apocalypse d'Abraham, 76. 
the visionary's spirit is said to have been affrighted and his soul to have fled himhe "became like a stone (быхъ яко камыюк)), and fell down upon the earth ( $u$ падохъ [яко] ниць на земли)."30

Transformational prostration of an adept during his dramatic encounter with the deity is not a novel feature and is customarily encountered in theophanic narratives as early as the book of Ezekiel, which depicts a visionary's prostration while approaching the glory of God. ${ }^{31}$ There is, however, a significant difference between these two mystical traditions, since in the Apocalypse of Abraham the visionary's prostration occurs not before the divine form but before the divine voice. Veneration of the divine sound can be found in other parts of the text where not only Abraham but also his celestial companion, Yahoel, is depicted as a worshiper of this peculiar divine manifestation:

And while he was still speaking, behold, a fire was coming toward us round about, and a sound was in the fire like a sound of many waters, like a sound of the sea in its uproar. An angel bowed with me and worshiped (и покляче съ мною ангель и поклонися). (Арос. Ab. 17:1-2) 32

\section{The Singer of the Eternal One}

It is important not to underestimate the figure of Abraham's celestial guide in the theological framework of the Slavonic apocalypse. Indeed, Yahoel can be seen as one of the decisive symbols for understanding the overarching theological thrust of the pseudepigraphon. The Apocalypse of Abraham defines him as the mediation of "my [God] ineffable name (неизрекомаго имени моего)."33 Even apart from this explanation of the guide's spectacular office, the peculiar designation Yahoel (Slav. Иаоиль) in itself reveals unequivocally the angelic creature as the representation of the divine name. It is no coincidence that in the text, which exhibits similarities to the Deuteronomic Shem theology, the angelic guide of the protagonist is introduced as the Angel of the Name. Scholars have previously noted the formative role of the figure of the Angel of the Name (or the Angel of YHwH) in the conceptual framework of the Deuteronomic and Deuteronomistic Shem ideologies. According to one of the hypotheses, the figure of the Angel of the Lord (or the Angel of the Divine Name) found in the book of Exodus constituted one of the conceptual roots

${ }^{30}$ Kulik, Retroverting the Slavonic Pseudepigrapha, 17; Rubinkiewicz, L'Apocalypse d'Abraham en vieux slave, 126; Philonenko-Sayar and Philonenko, L'Apocalypse d'Abraham, 58.

${ }^{31}$ See also 1 Enoch 71; 2 Enoch 22.

${ }^{32}$ Kulik, Retroverting the Slavonic Pseudepigrapha, 22; Philonenko-Sayar and Philonenko, L'Apocalypse d'Abraham, 72.

${ }^{33}$ Kulik, Retroverting the Slavonic Pseudepigrapha, 17; Rubinkiewicz, L'Apocalypse d'Abraham en vieux slave, 128; Philonenko-Sayar and Philonenko, L'Apocalypse d'Abraham, 58. 
of the Shem theology. Tryggve N. D. Mettinger observes that "it appears that when the Deuteronomistic theologians chose shem, they seized on a term which was already connected with the idea of God's presence. Exod 23:21 tells us how God warned Israel during her wanderings in the desert to respect his angel and obey his voice, 'for my name is in him."'34

Yahoel can be seen as both a manifestation and a nonmanifestation of the divine name. He is in many ways a paradoxical figure at once reaffirming the divine presence through the mediation of the Tetragrammaton and challenging its overt veneration. ${ }^{35}$ This ambiguity in his role of mediating the divine presence is very similar to the later role, in the Merkabah tradition, of the angel Metatron, who represents not only the divine name but also the form of the deity, his Shicur Qomah. ${ }^{36}$ In his role as a representation of the divine body, the great angel finds himself in a rather awkward position, as he becomes a stumbling block for the infamous visionary of the Talmud, Elisha b. Abuyah, who according to b. Hag. 15a took Metatron as the second deity in heaven, which led him to the heretical conclusion about two "powers" (ב' רשויות) in heaven. Still, in both accounts (talmudic and pseudepigraphical) the difference between the deity and his angelic manifestation is properly reaffirmed. In the Apocalypse of Abraham, Yahoel prevents Abraham from venerating him by putting the patriarch on his feet. In $b$. Hag. 15a the distance between the deity and his vice-regent, the angel Metatron, is reaffirmed even more radically-the supreme angel is publicly punished in front of the celestial hosts with sixty fiery lashes in order to prevent future confusions between the deity and his angelic replica. Despite these reaffirmations, the boundaries between the deity and his angelic manifestation in the form of his Shicur Qomah or the divine name do not remain entirely unambiguous. The paradoxical nature of this angelic mediation of the divine name appears to be hinted at in the Apocalypse of Abraham through the depiction of Yahoel delivering a prayer to the deity, a hymn that now paradoxically includes his own name, "Yahoel." 37

\section{Praxis of the Voice}

The identification of divine manifestation with the voice or the sound in the Apocalypse of Abraham underlines the importance of praise as a parallel process to

${ }^{34}$ Mettinger, Dethronement of Sabaoth, 124-25.

${ }^{35}$ Apoc. Ab. 10:4: "he took me by my right hand and stood me on my feet." Kulik, Retroverting the Slavonic Pseudepigrapha, 17.

${ }^{36} \mathrm{On}$ the formative influence of the Yahoel lore on the figure of Metatron, see Scholem, Jewish Gnosticism, 51.

${ }^{37}$ Apoc. Ab. 17:7-13: "And I recited, and he [Yahoel] himself recited the song: O, Eternal, Mighty, Holy El, God Autocrat ... Eternal, Mighty, Holy Sabaoth, Most Glorious El, El, El, El, Yahoel." Kulik, Retroverting the Slavonic Pseudepigrapha, 23. 
the aural expression of creation in relation to its Creator. Further, the authors of the text seem to view the praising of God as a mystical praxis that in many ways mirrors the visionary praxis of the Kavod paradigm. Scholars have previously observed the importance of aural invocation or "calling upon" in the Shem paradigm that had come to function as an act of actualization of the presence of God. ${ }^{38}$ By invoking the deity (or more precisely the divine name) in praise, the practitioner "brings" the deity into existence, ${ }^{39}$ summoning him from nonbeing into being, thus replicating the prototypical event of creation recounted in Genesis 1, where God himself brings everything into being by invoking the divine name. ${ }^{40}$

Time and again the angel Yahoel poses as a faithful adept of this mystical praxis of praise. The text defines him as the Singer of the Eternal One (Apoc. Ab. 12:4). He is exceptional both as a practitioner and as an instructor of this "aural mysticism," conveying the teachings of the praxis to various types of God's creatures, earthly as well as celestial. In Apoc. Ab. 10:8-9 he is described as the celestial choirmaster of the Hayyot:

I am a power in the midst of the Ineffable who put together his names in me. I am appointed according to his commandment to reconcile the rivalries of the Living Creatures of the Cherubim against one another, and teach those who bear him [to sing] the song in the middle of man's night, at the seventh hour. ${ }^{41}$

This role can again be compared to the future office of Metatron, who often appears in the Hekhalot and Shicur Qomah accounts as the celestial choirmaster ${ }^{42}$ conducting the liturgies of the Living Creatures. ${ }^{43}$

${ }^{38}$ Mettinger, Dethronement of Sabaoth, 125.

${ }^{39}$ The process of the constitution of the angelic or divine presence or the reconstitution of a human nature into a celestial one through the invocation of the divine name can be seen in the traditions about Moses' investiture with the divine name during his Sinai experience and Jesus' investiture with the divine name at his baptism. For a detailed discussion of these traditions, see Jarl Fossum, The Name of God and the Angel of the Lord: Samaritan and Jewish Mediation Concepts and the Origin of Gnosticism (WUNT 36; Tübingen: Mohr Siebeck, 1985), 76-112.

${ }^{40}$ In the Palestinian targumic tradition (Targum Neofiti; Fragmentary Targum) the divine command יהי uttered by God during the creation of the world is identified with the Tetragrammaton. For a detailed discussion of this tradition, see Fossum, Name of God, 80.

${ }^{41}$ Kulik, Retroverting the Slavonic Pseudepigrapha, 18. For an extensive discussion of the passages about the rivalries of the Hayyot in the Apoc. Ab. 10:8-9 and 18:8-10, see K. William Whitney, Jr., "Two Strange Beasts. A Study of Traditions Concerning Leviathan and Behemoth in Second Temple and Early Rabbinic Judaism” (Ph.D. diss., Harvard University, 1992), 94-96.

${ }^{42}$ On Metatron's role as the celestial choirmaster of the Hayyot, see Andrei A. Orlov, "Celestial Choirmaster: The Liturgical Role of Enoch-Metatron in 2 Enoch and the Merkabah Tradition," in idem, From Apocalypticism to Merkabah Mysticism: Studies in the Slavonic Pseudepigrapha (JSJSup 114; Leiden: Brill, 2007), 197-221.

43 "One hayyah rises above the seraphim and descends upon the tabernacle of the youth whose name is Metatron, and says in a great voice, a voice of sheer silence: 'The Throne of Glory is shining.' Suddenly the angels fall silent. The watchers and the holy ones become quiet. They 
Yahoel's expertise in heavenly praise does not seem to be limited to heavenly matters. In the apocalypse he is also depicted as the one who initiates a human visionary, the patriarch Abraham, into this mystical praxis of praising the deity, which serves here as an alternative practice to the vision mysticism.

And he said, "Only worship, Abraham, and recite the song which I taught you." ... And he said, "Recite without ceasing." And I recited, and he himself recited the song. (Apoc. Ab. 17:5-7). ${ }^{44}$

Our previous remarks about the connections between the visionary and aural praxis make it intriguing that veneration of the deity is described in the Apocalypse of Abraham through the paradoxical formula of seeing/not seeing: "He whom you will see (его же узриши) going before both of us in a great sound of qedushah is the Eternal One who had loved you, whom himself you will not see (самого же не зричи)" (Apoc. Ab. 16:3). ${ }^{45}$

This ambiguous mixture of the paradigms of vision and voice can be seen in other parts of the text as well. For example, in the depiction of Abraham's fast in 12:2, two mystical practices appear to be mixed:

And we went, the two of us alone together, forty days and nights. And I ate no bread and drank no water, because [my] food was to see the angel who was with me, and his speech with me was my drink. (Apoc. Ab. 12:1-2) (6 $^{46}$

Here the traditional motif found in the visionary accounts-viz., the motif of nourishment through the beholding of a celestial being, often in the form of the Kavod, that is especially famous in the later interpretations of Moses' story where he is often depicted as a being fed through the vision of God's Shekhinah-is paralleled with the motif of nourishment through the voice of the heavenly being, the angel Yahoel. $^{47}$

are silent, and are pushed into the river of fire. The hayyot put their faces on the ground, and this youth whose name is Metatron brings the fire of deafness and puts it into their ears so that they could not hear the sound of God's speech or the ineffable name. The youth whose name is Metatron then invokes, in seven voices, his living, pure, honored, awesome, holy, noble, strong, beloved, mighty, powerful name" (Peter Schäfer et al., Synopse zur Hekhaloth-Literatur [TSAJ 2; Tübingen: Mohr Siebeck, 1981] 164). Another Hekhalot passage attested in Synopse $\$ 385$ also elaborates the liturgical role of the exalted angel: "when the youth enters below the throne of glory, God embraces him with a shining face. All the angels gather and address God as 'the great, mighty, awesome God', and they praise God three times a day by means of the youth" (Synopse, 162-63). The designation of Yahoel as the Singer of the Eternal One in Apoc. Ab. 12:4 is also intriguing. It again recalls the description of Metatron in the aforementioned account, where he is depicted as the leading singer of the heavenly host, the one who is able to invoke the divine name in seven voices.

${ }^{44}$ Kulik, Retroverting the Slavonic Pseudepigrapha, 22-23.

${ }^{45}$ Ibid., 22; Philonenko-Sayar and Philonenko, L'Apocalypse d'Abraham, 70.

${ }^{46}$ Kulik, Retroverting the Slavonic Pseudepigrapha, 19.

${ }^{47}$ David Halperin notes some similarities between the celestial nourishments of Abraham and Moses. He observes that "Moses also discovered that the divine Presence is itself nourishment 
Also noteworthy is that in the Apocalypse of Abraham the praise seems to be understood as a sort of garment that envelops the formless deity, similar to the Merkabah tradition where the divine form is enveloped in the garment known as the Haluq (חלוק), an attribute that underlines the anthropomorphic nature of the divine "extent." In contrast, in Apoc. Ab. 16:2-4 the deity is enveloped in the sound of angelic praise, a description that may serve to reaffirm the bodiless presence of the deity: ${ }^{48}$

And he [Yahoel] said to me, "Remain with me, do not fear! He whom you will see going before both of us in a great sound of qedushah is the Eternal One who had loved you, whom himself you will not see. Let your spirit not weaken $<$ from the shouting $>$, since I am with you, strengthening you." (Apoc. Ab. 16:2-4) ${ }^{49}$

The importance of angelic praise is highlighted also in the depiction of the divine throne in ch. 18, which draws on the imagery found in Ezekiel 1. One of the new details there, however, is the persistent emphasis on the symbolism of vocal praxis: in their portrayals of the Living Creatures (the Hayyot) and the Wheels (the Ophannim), the authors accentuate their role in the praising of the deity:

And as the fire rose up, soaring higher, I saw under the fire a throne [made] of fire and the many-eyed Wheels, and they are reciting the song. And under the throne [I saw] four singing fiery Living creatures. (Apoc. Ab. 18:3) $)^{50}$

Thus, instead of emphasizing the role of the Hayyot as the foundation of the throne, which in the formative account found in the book of Ezekiel holds the divine presence/form, the Slavonic apocalypse stresses the praising functions of the Living Creatures depicted as "singing the divine presence."

\section{"No Other Power of Other Form"}

The most striking detail in the description of the divine throne in ch. 18, which radically differs from the Ezekielian account, is that at the climactic moment of the seer's encounter with the divine chariot-which also curiously appears to be missing a rider-the text does not give any indications of the presence of the anthropomorphic glory of God, which in Ezek 1:26 is described as דמות כמראה אדם.

enough. That is why Exod 24:11 says that Moses and his companions beheld God, and ate and drank. This means, one rabbi explained, that the sight of God was food and drink to them; for Scripture also says, In the light of the King's face there is life.... We might assume that the author of the Apocalypse of Abraham had such midrashim in mind when he wrote that 'my food was to see the angel who was with me, and his speech-that was my drink'" (Faces of the Chariot, 111).

${ }^{48}$ The concept of praise as a garment seems to be connected with the tradition of the investiture with the divine name discussed earlier in our article.

${ }^{49}$ Kulik, Retroverting the Slavonic Pseudepigrapha, 22.

${ }^{50}$ Ibid., 24. 
Instead of the Ezekielian anthropomorphic "extent," the visionary encounters the already familiar voice in the midst of fire surrounded by the sound of the qĕdî̌šâ:

While I was still standing and watching, I saw behind the Living Creatures a chariot with fiery Wheels. Each Wheel was full of eyes round about. And above the Wheels there was the throne which I had seen. And I was covered with fire and the fire encircled it round about, and an indescribable light surrounded the fiery people. And I heard the sound of their qedushah like the voice of a single man. ${ }^{51}$ And a voice came to me out of the midst of the fire. (Apoc. Ab. 18:12-19:1) $)^{52}$

Polemics with the divine body traditions is then further developed in ch. 19, which can be considered the climactic point of the anticorporeal ideology of the apocalypse. Here the seer is allowed to take a final look at the upper firmaments so that he-and, more importantly, his audience-may be assured that no divine form is present there. The account detailing this final gaze is rather lengthy:

And he [God] said, "Look at the levels which are under the expanse on which you are brought and see that on no single level is there any other but the one whom you have searched for or who has loved you." And while he was still speaking, and behold, the levels opened, <and $>$ there are the heavens under me. And I saw on the seventh firmament upon which I stood a fire spread out and light, and dew, and a multitude of angels, and a power of the invisible glory from the Living Creatures which I had seen above. $<$ But $>$ I saw no one else there. And I looked from the altitude of my standing to the sixth expanse. And I saw there a multitude of incorporeal spiritual angels, carrying out the orders of the fiery angels who were on the eighth firmament, as I was standing on its suspensions. And behold, neither on this expanse was there any other power of other form, but only the spiritual angels, and they are the power which I had seen on the seventh firmament. (Apoc. Ab. 19:3-7). ${ }^{53}$

Intriguingly, the text repeatedly stresses the absence of any corporeal manifestation of the deity, in one instance even using the term "form" (Slav. oбpaz): ${ }^{54}$ "and behold, neither on this expanse was there any other power of other form (образом силь иноя)." 55

${ }^{51}$ Halperin noted the paradigm shift from the visual plane to the aural plane: "Ezekiel's phrase 'like the appearance of a man,' becomes, in a concluding sentence, that plainly draws on the end of Ezek 1:28, "like the voice of a man'" (Faces of the Chariot, 108).

${ }^{52}$ Kulik, Retroverting the Slavonic Pseudepigrapha, 24.

${ }^{53}$ Ibid., 24-25.

${ }^{54}$ The Slavonic word образ can be also translated as "type," "image," "icon," or "symbol." See Izmail Sreznevskij, Материаль для словаря древнерусского языка по письменным памятникам [Materials for a Dictionary of Old Russian Language](3 vols.; St. Petersburg: Russian Imperial Academy of Sciences, 1883-1912), 2:539-42.

${ }^{55}$ Kulik, Retroverting the Slavonic Pseudepigrapha, 25; Philonenko-Sayar and Philonenko, L'Apocalypse d'Abraham, 80. 
Further, the text seems to deny even the presence of angelic "bodies" on the upper firmaments, constantly referring to angelic creatures found there as "incorporeal" (бесплотныхъ) or "spiritual" (духовныхъ) angels. What is important for our ongoing inquiry is that, according to the Apocalypse of Abraham, it is not a manifestation of the deity but the incorporeal angels who now represent "the power" (Slav. сила) that the seer beholds on the seventh firmament.

\section{The Idol of Jealousy}

The polemical "clash" between the Kavod and Shem ideologies reaches eschatological proportions in ch. 25, where God allows Abraham to behold the future temple polluted by the idol of jealousy:

I saw there the likeness of the idol of jealousy (подобие идола ревнования), as a likeness (nодобиe) of a craftsman's [work] such as my father made, and its stature was of shining copper, and a man before it, and he was worshiping it; and [there was] an altar opposite it and youth were slaughtered on it before the idol. And I said to him, "What is this idol, and what is the altar, and who are those being sacrificed, and who is the sacrificer, and what is the beautiful temple which I see, art and beauty of your glory that lies beneath your throne?" And he said: "Hear Abraham! This temple and altar and the beautiful things which you have seen are my image of the sanctification of the name of my glory (святительства имени славы моея), where every prayer of men will dwell, and the gathering of kings and prophets, and the sacrifice which shall establish to be made for me among my people coming from your progeny. And the stature you saw is my anger, because the people who will come to me out of you will make me angry. And the man you saw slaughtering is he who angers me. And the sacrifice is the murder of those who are for me a testimony of the close of judgment in the end of the creation. (Apoc. Ab. 25:1-6) ${ }^{56}$

This description once again provides a graphic example of the polemical interaction between the traditions of the divine glory and the divine name, where the imagery of both trends becomes closely intertwined. In this pivotal passage, the earlier motifs that the readers encountered in the first section of the pseudepigraphon dealing with the idolatrous practices of Abraham's father become explicitly invoked. The figures similar to those made in the house of Terah are now installed in God's temple. This idolatrous practice of worship to the figure of shinning copper, labeled in the story as "a likeness (подобие) of a craftsman's work," seems to be cautiously invoking the language of "likeness" known from the Priestly theophanic paradigm exemplified in Gen 1:26 and Ezekiel 1. The idolatrous prac-

${ }^{56}$ Kulik, Retroverting the Slavonic Pseudepigrapha, 29; Philonenko-Sayar and Philonenko, L'Apocalypse d'Abraham, 92. 
tices are then contrasted to the true worship, which is described in the now-familiar language of the Shem tradition. Here the future eschatological temple is portrayed as a dwelling place not for the abominable shining figure but for "the image of the sanctification of the name of my [God's] glory (святительства имени славы моея), where every prayer of men will dwell (в нюже вселится всяка молба мужьска)." It is apparent that the authors try to reinterpret the technical terminology of the Kavod tradition, merging it with the formulae borrowed from the Shem ideology. There is also no doubt that the authors' attitude to the anthropomorphic ideology remains polemical, which is shown unabashedly through labeling the shining figure as the idol of jealousy.

\section{Conclusion}

As has been shown, the Apocalypse of Abraham offers a complex mix of the Kavod and Shem conceptual developments, in which promulgation of the theology of the divine name and the praxis of the divine voice become linked with the theophanic imagery from the Priestly source, Ezekiel, 1 Enoch, and some other Second Temple accounts. The consequences of this polemical encounter between two important revelatory trends appear to have exercised lasting influence on both traditions. The developments found in the Slavonic apocalypse should not be interpreted simply as a rejection of anthropomorphic theism through the aural paradigm of the divine name. Rather, they should be seen as an adaptation of Merkabah imagery to the framework of this aural paradigm, which has led to the construction of a new symbolic universe ${ }^{58}$ in which two trends can coexist. ${ }^{59}$ This synthesis is intriguing and might provide important insights for understanding the character of later Jewish mystical developments, where the traditions about the divine form and the divine name appear to undergo creative conflation. As has been mentioned, the protagonist of the later Hekhalot and Shicur Qomah accounts, the supreme angel Metatron, is often depicted in these materials as the celestial choirmaster, who instructs the Living Creatures on fitting ways of praising the deity. These later mystical traditions also portray him as

${ }^{57}$ Philonenko-Sayar and Philonenko, L'Apocalypse d'Abraham, 92.

${ }^{58}$ This new symbolic universe manifests itself, for example, in the depiction of the throne room with its paradoxical imagery reflecting the visual and the aural traditions.

${ }^{59}$ The synthetic nature of adaptations taking place in the Slavonic pseudepigraphon has been noticed previously by other scholars. Thus, John Collins observes that the Apocalypse of Abraham "belongs to the same general period as 4 Ezra and 2 Baruch and shares some of their concerns about theodicy. In place of the Deuteronomic tradition, which informs these books, however, the mystical tendency of the early Enoch books is taken up here" (Apocalyptic Imagination, 225).

${ }^{60}$ On Metatron's title יהוה הקטן, see Andrei A. Orlov, The Enoch-Metatron Tradition (TSAJ 107; Tübingen: Mohr Siebeck, 2005), 136-43. 
divine name, the office that is reminiscent of the roles of Yahoel in the Apocalypse of Abraham. ${ }^{61}$

These later conceptual developments bring to mind Gershom Scholem's hypothesis about the existence of two streams that in his opinion constituted the background of the Metatron figure: one connected with Yahoel's figure and the other with the figure of the seventh antediluvian patriarch, Enoch. ${ }^{62}$ The roles and offices of these two apocalyptic heroes, who can in many ways be seen as exemplars of the revelatory paradigms of the divine form and the divine voice, later became reconciled in the figure of the chief protagonist of the Merkabah lore. In view of these important developments attesting to the afterlife of the Shem and the Kavod trends in the later Hekhalot mysticism, the changes that take place in the Apocalypse of Abraham should not be underestimated. It is possible that the Slavonic apocalypse, in which the mystical praxis of the divine name was unfolded amid the familiar Merkabah imagery, can be seen as an important conceptual nexus where the traditions of the divine name become polemically engaged with the visionary Merkabah paradigm, thus anticipating the process of the gradual unification of both conceptual streams in the later Jewish mystical lore. ${ }^{63}$

${ }^{61}$ Collins notes that "in all, Jaoel bears striking resemblance to Metatron in Hekhalot literature. Metatron is 'the little Yahweh' ( $3 E n .12)$, whose name is like the name of God himself ( $b$. Sanh. 38b)" (Apocalyptic Imagination, 228).

${ }^{62}$ The classic study by Gershom Scholem differentiates between two basic aspects of Metatron's lore that, in his opinion, were combined in rabbinic and Hekhalot literature. These aspects include the Enochic lore and the lore connected with the exalted figures of Yahoel and Michael. Scholem writes that "one aspect identifies Metatron with Jahoel or Michael and knows nothing of his transfiguration from a human being into an angel. The talmudic passages concerned with Metatron are of this type. The other aspect identifies Metatron with the figure of Enoch as he is depicted in apocalyptic literature... When the Book of Hekhaloth, or 3 Enoch, was composed, the two aspects had already become intertwined" (Jewish Gnosticism, 51).

${ }^{63}$ Kulik observes that the Apocalypse of Abraham can be seen as "representative of a missing link between early apocalyptic and medieval Hekhalot traditions" (Retroverting the Slavonic Pseudepigrapha, 1). 